\title{
Transmission of Phytophthora ramorum in Mixed-Evergreen Forest in California
}

\author{
Jennifer M. Davidson, Allison C. Wickland, Heather A. Patterson, Kristen R. Falk, and David M. Rizzo
}

First author: Pacific Southwest Research Station, U.S. Department of Agriculture Forest Service, P.O. Box 245, Berkeley, CA 94701; and second, third, fourth, and fifth authors: Department of Plant Pathology, University of California, One Shields Ave., Davis 95616.

Current address of J. M. Davidson: Department of Zoology, 2538 McCarthy Mall, Edmondson 152, University of Hawaii, Honolulu 96822. Accepted for publication 26 January 2005.

\begin{abstract}
Davidson, J. M., Wickland, A. C., Patterson, H. A., Falk, K. R., and Rizzo, D. M. 2005. Transmission of Phytophthora ramorum in mixedevergreen forest in California. Phytopathology 95:587-596.

During 2001 to 2003, the transmission biology of Phytophthora ramorum, the causal agent of sudden oak death, was studied in mixedevergreen forest, a common forest type in northern, coastal California. Investigation of the sources of spore production focused on coast live oak (Quercus agrifolia) and bay laurel (Umbellularia californica), dominant hosts that comprised 39.7 and $46.2 \%$ of the individuals at the study site, respectively. All tests for inoculum production from the surface of infected coast live oak bark or exudates from cankers were negative. In contrast, sporangia and chlamydospores were produced on the surface of infected bay laurel leaves. Mean number of zoospores produced from infected bay laurel leaves under natural field conditions during rainstorms

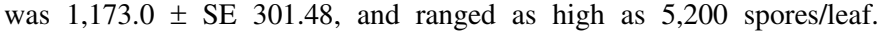

during the mid- to late rainy season in all 3 years of the study. P. ramorum was not recovered from sporadic summer rains or soil and litter during the hot, dry summer months. Concentrations of inoculum in rainwater varied significantly from year to year and increased as the rainy season progressed for the two complete seasons that were studied. Potential dispersal distances were investigated for rainwater, soil, and streamwater. In rainwater, inoculum moved 5 and $10 \mathrm{~m}$ from the inoculum source. For soil, transmission of inoculum was demonstrated from infested soil to bay laurel green leaf litter, and from bay laurel green leaf litter to aerial leaves of bay laurel seedlings. One-third to one-half of the hikers tested at the study site during the rainy season also were carrying infested soil on their shoes. In streamwater, $P$. ramorum was recovered from an unforested site in pasture $\approx 1 \mathrm{~km}$ downstream of forest with inoculum sources. In total, these studies provide details on the production and spread of $P$. ramorum inoculum in mixed-evergreen forest to aid forecasting and managing disease transmission of this environmentally destructive pathogen.
\end{abstract} $P$. ramorum was recovered from rainwater, soil, litter, and streamwater
Phytophthora ramorum, the causal agent of sudden oak death, is an emerging pathogen threatening oak woodlands in northern and central coastal California $(46,47)$. First noticed in the San Francisco Bay Area in the mid-1990s, the pathogen's geographic range in natural ecosystems currently extends over a range of $650 \mathrm{~km}$ from south of Big Sur, CA to Curry County in southwestern Oregon (46). Originally thought to be a pathogen of oak (Quercus sections Lobatae and Protobalanus) and tanoak (Lithocarpus densiflorus), P. ramorum is now known to infect over 20 woodland hosts and over 30 nursery hosts $(9,11,25,36,47,57)$. However, the majority of these infections are not lethal $(13,16$, 45). Oak and tanoak trees remain the species most at risk, with current estimates of mortality rates that are two and four times above historical levels for these two species, respectively (52). Subsequent loss of oak and tanoak from California woodlands may have grave ecological impacts. These species are dominant in many forests and serve as ecological keystone species that provide food and habitat for animals, serve as fire breaks, and host mycorrhizal networks (43).

Several lines of evidence suggest that $P$. ramorum is an introduced pathogen in California oak woodlands. First, the geographic range of $P$. ramorum is limited and considerably smaller than the geographic range of susceptible hosts $(24,46)$. Second,

Corresponding author: J. M. Davidson; E-mail address: jmd@hawaii.edu

DOI: 10.1094/PHYTO-95-0587

This article is in the public domain and not copyrightable. It may be freely reprinted with customary crediting of the source. The American Phytopathological Society, 2005. some hosts, like tanoak, exhibit unsustainably high levels of susceptibility to $P$. ramorum and may be driven extinct by the pathogen (52). Finally, in U.S. forests, the genetic variation of the $P$. ramorum population appears limited, and only one mating type (A2) has been found in these populations (28). Regardless of the exact origin of $P$. ramorum, whether it is exotic or an emerging strain of a native Phytophthora spp., the geographic range of this pathogen continues to expand locally within and beyond infested regions into previously uninfested areas of natural ecosystems in California and Oregon.

Over larger geographic scales, movement of infected nursery plants constitutes one of the greatest risks for spread of $P$. ramorum to forests. Within the past year, trace-back surveys have documented the movement of infected ornamental plants between nurseries in California, Oregon, Washington, and British Columbia outside of the range of the pathogen in forest (42). In addition, the recent discovery of the shipment of thousands of plants from an infested block in a large-scale nursery operation in southern California to destinations across the United States highlights the difficulty of containing P. ramorum on nursery stock under current trade policies (1). Subsequent introduction and establishment of $P$. ramorum in forests in new geographic areas via outplanting of infested ornamental plants is a genuine possibility given the proximity of housing to wildlands and the wide host range of this pathogen in temperate forests. An additional risk of the nursery trade includes the potential introduction of the second mating type, A1, to forests. The A1 mating type was discovered in nurseries in Oregon, Washington, and British Columbia in 2003 (21).

Consequently, $P$. ramorum poses a threat of increased destruction to temperate forests on local and expanding geographic 
scales in the United States. Current efforts to control the local spread of $P$. ramorum within forests include eradication and fungicide treatments $(14,15)$. However, these control measures may have limited success and are financially expensive to implement. In addition, eradication involves great environmental costs as the forest is cut and repeatedly burned. The environmental costs of phosphonate-based fungicide application to U.S. forests are unknown at this time (22). In order to design better management strategies for controlling the local spread of $P$. ramorum once it is introduced to forests, it is of utmost importance to understand the transmission biology of this pathogen in wildlands.

Most Phytophthora spp. have a disease cycle that involves infection of host tissue, production of infective spores (sporangia with motile zoospores), movement of infective spores, and reinfection of host tissue. In addition, resting spores (chlamydospores or oospores) may be produced to serve as a reservoir of inoculum for the pathogen during times unfavorable for growth or infection. Once spores are produced by Phytophthora spp. in natural areas, they typically can be moved through rain splash, watercourses, movement of infested soil, and, rarely, through wind without rain $(12,45)$. The characteristics of each one of these steps will affect rates of transmission and the geographic scale over which transmission occurs. In addition, transmission likely will vary for each of the host species of a multihost pathogen like $P$. ramorum.

Under laboratory conditions, $P$. ramorum readily produces sporangia and chlamydospores (10). Laboratory tests also have demonstrated the production of oospores, sexual dormant spores, on carrot agar and within rhododendron stem pieces $(5,58)$. However, we know little of how $P$. ramorum reproduces and spreads under natural conditions from multiple host plants in the forest.

The transmission biology of $P$. ramorum in natural areas is complicated, given that this pathogen infects over 20 hosts in a mosaic of forest types in California and Oregon. In this study, the spore production and movement steps of transmission for $P$. ramorum were investigated in one of the most common and ecologically important forest types: mixed-evergreen forest dominated by coast live oak (Quercus agrifolia) and California bay laurel (Umbellularia californica) (2). The geographic range of mixed-evergreen forest containing coast live oak extends from Mendocino County in the north $\left(40^{\circ} \mathrm{N}\right)$ into southern San Diego County $\left(32^{\circ} \mathrm{N}\right)$ and extends 60 to $120 \mathrm{~km}$ inland along the coast $(2,6,24)$. Data from plot monitoring indicate that incidence of $P$. ramorum infection on coast live oak in mixed-evergreen forests often is high (4 to 30\%), and that mortality levels are two times higher than historical levels (52; J. Davidson, unpublished data). Other important species in this forest type, all of which are hosts for $P$. ramorum, include California black oak ( $Q$. kelloggii), Douglas-fir (Pseudotsuga menziesii), and Pacific madrone (Arbutus menziesii) (2).

The objectives of this study were to determine the main sources of inoculum, the seasonality of inoculum production, and the transmission pathways of inoculum in a mixed-evergreen forest. Knowledge of the transmission biology of $P$. ramorum in this forest type will provide initial data to predict periods of high spore production and to forecast dispersal distances through rainwater, soil, and streamwater.

\section{MATERIALS AND METHODS}

Research site. Field work for this study was primarily carried out at Fairfield Osborn Preserve (FOP), Sonoma County, CA $\left(122^{\circ} 35^{\prime} 41^{\prime \prime} \mathrm{W}, 38^{\circ} 20^{\prime} 37^{\prime \prime} \mathrm{N}\right)$. FOP covers 166 ha and includes multiple types of mixed-evergreen forest, white oak ( $Q$. garryana) forest, and redwood forest in close proximity. The research site within the preserve encompassed approximately 25 ha of mixed-evergreen forest at an elevation of $530 \mathrm{~m}$. This area has a typical Mediterranean climate, with cool, wet winters and hot, dry summers, although summer fog can condense on foliage and drip into the understory. Rainfall at the site ranged between 880 and $1,280 \mathrm{~mm}$ per year and temperature ranged between -3 and $45^{\circ} \mathrm{C}$ during 2001 to 2003 (J. Clothier, unpublished data). Soils in this area are in the Goulding, Toomes, Spreckles, and Raynor series (38) and soil $\mathrm{pH}$ at the site ranged between 5.0 and 5.6 (J. Davidson, unpublished data). On a 1-ha plot survey within the site, coast live oak and bay laurel comprised 39.7 and $46.2 \%$ of the individuals, respectively. Infection levels within the plot were high: $16.5 \%$ for coast live oak and $81.9 \%$ for bay laurel (J. Davidson, unpublished data). Consequently, these two dominant hosts, coast live oak and bay laurel, were chosen as the focus for transmission studies.

Host plant study species. Coast live oak is an evergreen oak in the section Lobatae (red oaks). These trees grow to 10 to $25 \mathrm{~m}$ in height and up to $3.5 \mathrm{~m}$ in diameter (24). They commonly live up to 250 years and are keystone members of woodland communities. $P$. ramorum forms cankers in the phloem of coast live oak trees larger than $10 \mathrm{~cm}$ diameter breast height. Cankers generally are found on the main trunk within $1 \mathrm{~m}$ of the ground and commonly ooze a clear, red exudate (47). These infections have resulted in mortality as high as $20 \%$ in some stands (T. Swiecki and E. Bernhardt, unpublished data).

Bay laurel is a canopy tree of medium stature. This tree is of ecological importance because it provides habitat and food for wildlife (6). P. ramorum forms foliar lesions on bay laurel $(11,13)$ that most likely reduce photosynthetic ability in attached leaves (40) and also lead to higher rates of leaf abscission (J. Davidson, unpublished data). However, infection does not progress into the stem or main trunk, and never has been noted to cause mortality in this species (J. Davidson, unpublished data; P. Maloney, unpublished data).

Sources of spores. Coast live oak bark cankers. To test for the presence of inoculum (e.g., sporangia, zoospores, and chlamydospores) in the bleeding exudate from coast live oak cankers, exudate samples were collected from 27 infected coast live oak trees at FOP every 7 to 15 days during February to June 2003 and plated on pimaricin-ampicillin-rifampicin-pentachloronitrobenzene-selective agar (PARP) (12). Not all trees were exuding on a given sample date; therefore, not all trees were sampled on each date. However, all trees were sampled at least once for a total of 157 samples on 14 sampling dates. For each sample, 12 swabs of exudate were collected with a clean, wooden toothpick and swiped into the agar of a PARP plate. Exudate was not collected from bark that had been cut for previous isolation of $P$. ramorum from oak trees. In addition, care was taken not to include small pieces of bark that could have fallen from the phloem of cut surfaces. No further isolations from bark shavings were attempted during the exudate collection period. Plates were assessed for colony formation at 2 to 3 weeks and at 3 months, as an indication of the presence of viable $P$. ramorum in exudate.

To test for the presence of inoculum formed on the outer bark of coast live oak trees infected with $P$. ramorum, 18 logs with $P$. ramorum cankers were placed inside a plastic cage $(300 \mathrm{~cm}$ long by $90 \mathrm{~cm}$ wide by $110 \mathrm{~cm}$ high) within a growth chamber and monitored for inoculum production. A smaller control cage (40 $\mathrm{cm}$ long by $25 \mathrm{~cm}$ wide by $110 \mathrm{~cm}$ high) that did not contain logs also was placed inside the chamber. Logs were tested in groups of two to seven, depending on when they were cut. The logs each were cut from a separate, naturally infected oak tree growing in coast live oak-bay laurel forest at one of three sites: the Marin Open Space District (Marin County), Camp Tamarancho (Marin County), or along Lichau Road (Sonoma County). Logs were $30 \mathrm{~cm}$ long, and ranged in diameter from 20 to $89 \mathrm{~cm}$. Phloem within the cankers was moist, and $P$. ramorum recently had been isolated from these cankers, indicating that the pathogen was alive in the logs. Logs were cut in the rainy season or early summer (February to June 2002 and 2003) when P. ramorum was likely to be active and trunk moisture content was high. 
The environment in the growth chamber was set to conditions shown to favor sporulation by $P$. ramorum in the laboratory. Temperature was $20^{\circ} \mathrm{C}$ during the day and $15^{\circ} \mathrm{C}$ at night, optimal temperatures for spore production (described below). Day length was $12 \mathrm{~h}$. Logs and control were misted for $20 \mathrm{~s}$ every $2 \mathrm{~h}$ to maintain a film of moisture on the bark surface, a favorable condition for sporangia production. In addition, the logs and control were watered for $25 \mathrm{~s}$ two times per week using a sprinkling can with distilled water $\left(\mathrm{diH}_{2} \mathrm{O}\right)$ to simulate rain that could wash or splash zoospores and deciduous sporangia from the bark. The sprinkling can head had a 1-mm-diameter pore size and held a volume of 5 liters. Six 1-gallon Rhododendron 'Catawbiense Grandiflorum' plants, a rhododendron variety susceptible to P. ramorum (57), were placed around the logs to serve as trap plants. One plant was placed in the control cage. For nine of the logs, eight d'Anjou pear fruit also were placed at a distance of $\approx 20 \mathrm{~cm}$ from the logs and one fruit was placed in the control cage on a weekly basis. D'Anjou pear have been used successfully to bait $P$. ramorum from soil and streamwater (described below). In addition to the trap plants, water was collected from the log and control cages and filtered as described for rainwater (described below) to assess the presence of inoculum in the runoff water from the infected logs. Each trial lasted for 8 weeks. In all, 430 liters of runoff water were tested from the log cage, and 65 liters were tested from the control cage. At the end of the 8-week period, viability of $P$. ramorum in oak logs was tested again via isolation from infected bark pieces plated on PARP.

To more directly assess the potential for sporulation of $P$. ramorum on coast live oak bark, four pieces of canker-affected bark were removed from the ends of 15 of the logs in the growth chamber experiment to observe in moist chambers in the laboratory. Logs from which cankers pieces were cut were collected during February to June 2003 . Each canker piece measured $\approx 5$ by $9 \mathrm{~cm}$ at the surface of the bark, and extended $\approx 6 \mathrm{~cm}$ into the tree. Therefore, pieces included outer bark, phloem, and xylem. Canker-affected bark pieces were placed in clear plastic moist chambers (crispers) (17 $\mathrm{cm}$ long by $12 \mathrm{~cm}$ wide by $7 \mathrm{~cm}$ high) with the outer bark side up. To maintain high moisture levels, $\mathrm{diH}_{2} \mathrm{O}$ was added up to 0.5 to $1 \mathrm{~cm}$ below the surface of the outer bark, the surface of the bark was regularly misted with $\mathrm{diH}_{2} \mathrm{O}$ to maintain a film of water on the bark, and crispers were sealed with Vaseline. The surface of the bark was checked for the presence of spores with a dissecting scope on a weekly basis for 6 weeks. In addition, hyphae extending from exposed phloem on the side surfaces of the piece were monitored and plated on PARP to verify the presence of $P$. ramorum.

Bay laurel leaves. Infected bay laurel leaves were collected from trees at $\mathrm{FOP}$ and floated on $\mathrm{diH}_{2} \mathrm{O}$ to test for spore production. In each of three trials, one infected leaf was collected from each of 20 trees separated spatially throughout the preserve study site for a total of 20 leaves. In the first two trials, conducted in May and June 2002, respectively, two to six leaf disks were cut from the leaf lesion and floated on approximately $8 \mathrm{ml}$ of $\mathrm{diH}_{2} \mathrm{O}$ in $15-\mathrm{ml}$ petri dishes. Disks were examined daily for 1 week, and then once at 2 weeks, for the presence of sporangia and chlamydospores. In the third trial, in February 2003, entire infected leaves were placed on a plastic grid in a moist chamber (crisper) ( $17 \mathrm{~cm}$ long by $12 \mathrm{~cm}$ wide by $7 \mathrm{~cm}$ high) with $\mathrm{diH}_{2} \mathrm{O}$ added just to leaf level. In this trial, leaf material was examined with the dissecting scope at 3 days and then weekly thereafter for 6 weeks for the presence of sporangia and chlamydospores.

Infected bay laurel leaves at FOP were observed on site for sporangia production on two dates (14 March 2003 and 25 April 2003) approximately $24 \mathrm{~h}$ into a rainstorm. An infected leaf was collected from each of 20 trees throughout the preserve study site. Leaves were kept moist and immediately carried to the dissecting scope for observation. Presence or absence of sporangia on the leaves was noted.
On the second date, inoculum levels per leaf were quantified after observation. The necrotic section of the leaf, in addition to a border of healthy, green tissue, was cut and placed in a 2-ml snapcap tube with $1.5 \mathrm{ml}$ of sterile $\mathrm{diH}_{2} \mathrm{O}$. Virtually all sporangia were observed on the lower side of the leaf; therefore, the leaf was put in the tube with the upper side touching the tube wall. Leaves in tubes then were placed on ice for 45 min to shock any sporangia into releasing zoospores. Afterward, tubes were incubated at $20^{\circ} \mathrm{C}$ for $12 \mathrm{~h}$ to encyst zoospores, allowing for a more uniform mixture to determine concentration. Tubes then were vortexed, and $200 \mu \mathrm{l}$ was plated onto PARP plates. Colonies were counted at 24 and $48 \mathrm{~h}$ to determine the number of zoospores present on bay laurel leaves under natural conditions.

The effect of temperature on sporangia production from bay laurel leaves was tested in the laboratory. To ensure bay laurel leaves were infected with $P$. ramorum to an equal extent, experimental leaves were inoculated in the laboratory. Ten leaves from each of 15 trees at FOP were collected. Each set of 10 leaves was infected with a zoospore solution (approximately $10^{5}$ spores per $\mathrm{ml}$ ) from an isolate that had been recovered from the same tree as the set of leaves. Then, from each set of 10 leaves, 6 leaves with the largest lesions were selected for the temperature experiment. These leaves were surface sterilized in $70 \% \mathrm{EtOH}$ for $60 \mathrm{~s}$ to kill remaining zoospores and any sporangia that had formed during the inoculation process. One leaf from each of the 15 trees was then randomly assigned to one of six temperature treatments $(5$, $10,15,20,25$, and $30^{\circ} \mathrm{C}$ ), for a total of 15 leaves in each treatment. For each temperature treatment, a disk was cut from the border of the lesion on each of the 15 leaves with a quarter-inch hole punch and floated on $1 \mathrm{ml}$ of sterile $\mathrm{diH}_{2} \mathrm{O}$ in a 24 -well plate. Plates then were incubated at the prescribed temperature for $48 \mathrm{~h}$. After incubation, all plates were set at $4^{\circ} \mathrm{C}$ for 30 min to shock any sporangia present, and then set at room temperature for $1 \mathrm{~h}$ to allow for zoospores release. Leaf disks were removed and plates set at $5^{\circ} \mathrm{C}$ for $12 \mathrm{~h}$ to allow zoospores to encyst to facilitate quantification. To quantify the number of zoospores produced, $50-$ and $100-\mu l$ aliquots from each well were plated on PARP. Colonies were counted at 24 and $48 \mathrm{~h}$ and results calculated for total number of zoospores produced by each leaf disk at a given temperature. Results from the two aliquots were averaged. Differences in numbers of zoospores produced at each temperature were analyzed with analysis of variance (ANOVA). To meet the assumptions of ANOVA, temperature treatments that resulted in no zoospore production were excluded from the statistical analysis.

Transmission pathways and seasonality of inoculum. Once spores of Phytophthora are produced, they typically can move through rain splash, soil, and streamwater (45). These substrates were sampled for inoculum of $P$. ramorum throughout 2001 to 2003 to determine when inoculum was present. The distance $P$. ramorum could spread via each of these pathways also was investigated.

Rainwater. Rainwater was collected in traps placed throughout the FOP study site. Rain traps consisted of a vinyl sheet (165 by $75 \mathrm{~cm}$ ) stretched over a polyvinyl chloride (PVC) frame and folded into a funnel with a 3.8-liter (1-gallon) collecting jar at the bottom. Traps were set up in February 2001 and used to collect rainfall throughout the year until October 2003. Initially, 24 traps were placed in the woodland around infected coast live oak and bay laurel trees. An additional 6 traps were installed in March 2001 for a total of 30 traps.

During the rainy season, rainwater was collected from individual storm events (duration 1 to 6 days) approximately every 10 days. During the summer, rainstorms were a rare event, and all rainfalls of 0.5 liters or more were collected. After collection, rainwater either was processed that day or allowed to sit overnight at 4 to $5^{\circ} \mathrm{C}$ before processing. Processing consisted of filtering the rainwater through miracloth (VWR 80058394) to remove coarse debris and then through a millipore glass fiber prefilter (Fisher 
APFD04700090500) with a capture size of $2.7 \mu \mathrm{m}$. The smallest $P$. ramorum propagules, zoospores, are approximately $10 \mu \mathrm{m}$ in diameter. Consequently, all spores would be caught by the filter. The filter then was cut into strips and placed filtrate side down on PARP. After 3 to 4 days, strips were removed and colonies of $P$. ramorum were counted under the microscope by marking the position of the colony on the plate. Plates then were examined every 3 to 4 days until 14 days after the initial plating to mark any additional colonies. At 21 days after the initial plating, a final check was made to verify that marked colonies matched $P$. ramorum morphology. The actual $P$. ramorum colonies then were counted. When there were large numbers of colonies, only a subset of the plate was counted. One colony was used as an indication of one viable propagule of $P$. ramorum. Results were calculated in terms of colony forming units (CFU) per liter.

Statistical analyses were used to characterize patterns in spore production data. Differences in the quantity of spores produced in each rainy season were tested with a one-way ANOVA. The ANOVA was weighted by the inverse of the variance of the residuals $(41,56)$ because standard transformations did not control for unequal variances among treatment means as indicated by a Levene's test (33). Variation in spore production with time (days) throughout the rainy season was tested separately for each year using linear regression. A standard Bonferroni correction was applied to each of the three analyses to correct for type 1 error due to multiple tests of a common hypothesis (51). For each of the two complete rainy seasons (2001-02 and 2002-03), stepwise linear multiple regression was used to test the predictive value of mean daily high temperature, mean daily low temperature, and mean daily precipitation on mean CFU/liter for all traps during the rain event. The stepwise criterion was run with a backwards direction with $P>0.1$ for $F$ for variable removal. These analyses and all others in this article were performed with JMP-IN 5.1 (48).

Weather data for analyses were obtained from FOP (J. Clothier, unpublished data). The FOP weather station stands in the open in a small meadow within the research site. Daily high and low temperatures were measured with a mercury max-min thermometer and cumulative daily precipitation was measured with a manual rain gauge. Daily high, low, and average air temperature also was measured with a Campbell HMP45C-L10 temperature and relative humidity probe under nearby forest cover from March 2003 to March 2004. Weather data measured under forest cover were significantly correlated $(P<0.0001)$ with data taken in the open during this same period $\left(R^{2}=0.71\right.$ to 0.72$)$, indicating that the FOP weather station data used in analyses were reflective of forest conditions. However, low and high temperatures were less extreme under forest cover (J. Clothier, unpublished data; J. Davidson, unpublished data).

To determine the distance that inoculum travels in rainwater and to construct initial estimates of the distance that $P$. ramorum could spread during a single rainstorm, rainwater was collected in 7.5-liter buckets placed in a meadow in 12 transects extending out from infected bay laurel trees at the forest-meadow edge. Transects extended out to the southwest in the direction of prevailing winds (J. Clothier, personal communication). For each transect, buckets were placed at 0 and $5 \mathrm{~m}$, for a total of 12 buckets at each distance. Because the meadow narrowed, buckets were placed at $10 \mathrm{~m}$ for only 11 of the 12 transects, for a total of 11 buckets. In addition, for two transects, buckets were placed at $15 \mathrm{~m}$ from the forest edges. Rainwater was collected during five rain events and assessed for spores as described for the forest rain traps to determine the quantity of propagules that traveled a given distance from the inoculum source. The effect of distance from source $(0$, 5 , and $10 \mathrm{~m}$ ) on the quantity of propagules was assessed with linear regression. If no propagules were found at any of the three distances for a transect on a given rain date, those data were excluded from analysis.
Soil and litter. Beginning in 2001, soil and litter were collected on a monthly basis from around the base of 15 diseased oak trees at the FOP study site to test for the presence of $P$. ramorum. Sampling from soil and litter began in February and March 2001, respectively, and continued through October 2003. Previous isolations confirmed that all oak trees were infected by P. ramorum. Equal amounts of soil to a depth of $10 \mathrm{~cm}$ were collected from three separate spots within $1.5 \mathrm{~m}$ of the base of each tree and pooled to equal $500 \mathrm{~g}$. A pooled quantity of $1,200 \mathrm{ml}$ of leaf litter also was collected from three spots for analysis. A washed, green d'Anjou pear fruit was submerged into the soil or litter in each sample so that one-third of the pear was immersed, and $\mathrm{diH}_{2} \mathrm{O}$ was added to the sample until one-half of the pear was immersed in water. Samples were allowed to sit for 6 days at 18 to $23^{\circ} \mathrm{C}$. Pear fruit then were removed, washed, and monitored for signs of Phytophthora lesions. Tissue from likely lesions was plated on PARP selective medium to verify $P$. ramorum presence. The relationship between (i) positive soil samples and CFU/liter of rainwater and (ii) positive litter samples and CFU/liter of rainwater were assessed with linear regression.

From October 2002 to October 2003, percent soil water content was calculated for each of the 15 soil samples. From each sample, approximately $5 \mathrm{~g}$ of mixed, collected soil was placed in aluminum drying tins and the weight of the soil was measured before and after drying at $65^{\circ} \mathrm{C}$ for 5 days.

Human spread of inoculum of $P$. ramorum via movement of infested soil on shoes was monitored at the FOP study site by pearbaiting soil from hiker's shoes in two trials during April 2003. In each trial, soil samples were collected from the shoes of five schoolchildren who had hiked the same 2.4-km trail. Each soil sample was scraped into a separate $945-\mathrm{ml}$ plastic bowl using sterile tongue depressors and a $\operatorname{diH}_{2} \mathrm{O}$ wash. This sampling was repeated on three consecutive days, with different groups of children each day, for a total of 15 independent soil samples in each trial. Washed d'Anjou pear fruit were added to the soil mixture and the baiting procedure detailed in the soil monitoring section (described previously) was followed. Results were noted as the number of children transporting infested soil on their shoes.

The potential for $P$. ramorum spores in soil to infect green leaves lying on the surface of the soil was tested. Moistened, sterile potting soil was placed in a standard nalgene autoclave bin (45 $\mathrm{cm}$ long by $38 \mathrm{~cm}$ wide by $13 \mathrm{~cm}$ high) and inoculated with a suspension of encysted zoospores of $P$. ramorum to deliver approximately 65,000 spores evenly on the soil surface. Fifteen detached leaves of bay laurel were gently placed on top of the infested soil. The leaves were misted with $\mathrm{diH}_{2} \mathrm{O}$, and the bin was wrapped in plastic and stored at room temperature $\left(18\right.$ to $\left.23^{\circ} \mathrm{C}\right)$ in the laboratory. Leaves were checked for signs of infection and misted weekly for 8 weeks. Symptomatic leaves were removed and plated on PARP to verify that lesions were caused by $P$. ramorum. Two trials of this experiment were conducted.

In a second experiment, the potential for P. ramorum to spread from infested bay laurel green leaf litter to aerial parts of seedlings was tested. Six bay laurel seedlings (approximately $12 \mathrm{~cm}$ tall) in cone containers were placed in potting soil in a 68-liter Tupperware bin $(50 \mathrm{~cm}$ long by $38 \mathrm{~cm}$ wide by $40 \mathrm{~cm}$ high). Symptomatic bay laurel leaves collected from multiple trees in infested coastal forests (China Camp State Park in Marin County, Marin Municipal Water District, and FOP) were placed as leaf litter on top of the soil around the bay laurel seedlings. Care was taken to ensure that seedling leaves did not touch the infected bay laurel litter leaves. A control bin also was set up with six bay laurel seedlings, but no litter leaves. Each seedling bin then was placed within a cage of plastic sheeting inside of a growth chamber with a 12-h day and day and night temperatures of 15 and $12^{\circ} \mathrm{C}$ (trial 1 ) or 20 and $15^{\circ} \mathrm{C}$ (trial 2), respectively. Seedling bins were misted with $\mathrm{diH}_{2} \mathrm{O}$ for $20 \mathrm{~s}$ every $2 \mathrm{~h}$. In addition, a rain treatment was applied two times per week. The rain treatment 
consisted of watering the bin with a sprinkling can from a height of approximately $1 \mathrm{~m}$ for $25 \mathrm{~s}$ to simulate raindrops (described previously). Seedling leaves were checked biweekly for signs of infection for 8 weeks. Symptomatic leaves were plated on PARP to verify that the lesion was caused by $P$. ramorum. A positive $P$. ramorum lesion on a seedling leaf was counted as an incident of transfer of inoculum from the leaf litter source up to the seedling leaves. Two trials of this experiment were conducted.

Streamwater. The presence of $P$. ramorum in an ephemeral creek traveling through the study site at FOP was monitored. This waterway was a tributary of Copeland Creek and flowed only during heavy rainstorms. The creek was sampled for $P$. ramorum twice during the 2001-02 rainy season, a particularly dry year, and at least once per month from January through May for a total of seven sampling periods during the 2002-03 rainy season, which had more consistent rainfall. Sampling consisted of placing one mesh bag with four washed d'Anjou pear fruit at each of three locations where watered pooled more slowly in the stream. Bags were floated with packing peanuts, packing bubbles, or fishing floats to keep fruit at surface level where zoospores may be more likely to swim. Pear fruit were left in the stream for 4 to 5 days and then removed, washed, and monitored for signs of Phytophthora lesions. Tissue from suspected lesions was plated on PARP to verify $P$. ramorum presence.

In a second study, the presence of $P$. ramorum downstream of the FOP study site in Copeland Creek was monitored as an indication of how far $P$. ramorum could travel in streamwater. Rhododendron leaf baits were placed in the stream at FOP, and then downstream at 4 and $6 \mathrm{~km}$ during two sampling periods in the 2003 rainy season. The first site downstream $(4 \mathrm{~km}$ from FOP) was still under coast live oak and bay laurel canopy. Leaves of bay laurel at this site were infected with P. ramorum. However, the second site ( $6 \mathrm{~km}$ from FOP) was downstream of forest by 1 $\mathrm{km}$ in a riparian corridor extending through pasture. Bay laurel was absent along this $1-\mathrm{km}$ stretch of the stream. Toxicodendron diversilobum (poison oak), a winter deciduous host of $P$. ramorum, occurred at very low abundance at the second site but was not symptomatic. No other known hosts were present, nor did the riparian plants appear symptomatic. Five baits consisting of a Rhododendron 'Colonel Coen' leaf in a 5-by-10-cm screen bag were tied on string and floated in the stream at each of the three sites. Rhododendron Colonel Coen is highly susceptible to P. ramorum (D. Rizzo, unpublished data). Baits were left in the stream for 2 weeks. Leaves then were removed and lesions plated on PARP to verify presence of $P$. ramorum.

\section{RESULTS}

Sources of spores. Coast live oak bark cankers. All tests for inoculum production on coast live oak were negative for spore production. None of the 157 exudate samples collected throughout the rainy season resulted in growth of P. ramorum on PARP plates. For the logs with cankers in the growth chamber, none of the bait rhododendron plants or the bait pear fruit became infected with $P$. ramorum. However, $P$. gonapodyides was isolated from lesions on three pear fruit and identified using molecular diagnostics. Similarly, no colony growth occurred from the 430 liters of runoff water collected and filtered from the log cage, although $P$. ramorum was re-isolated from 6 of the $18 \operatorname{logs}$ at the end of the experiment by plating bark chips onto PARP plates. The control cage also was negative in all baiting and runoff water tests for $P$. ramorum. In addition, no spores (sporangia or chlamydospores) were observed on the intact outer bark surface of the canker pieces set in moist chambers. However, hyphae of $P$. ramorum grew from the cut surface of exposed phloem and extended out into the water from one canker piece each from 2 of the 15 trees. Chlamydospores were produced on the hyphae in the water. Hyphae were verified as $P$. ramorum by plating onto PARP.
Bay laurel leaves. P. ramorum produced large numbers of sporangia from infections on bay laurel leaves under laboratory and natural conditions. In the three trials conducted in laboratory moist chambers, $17 / 20$ (85\%), 18/20 (90\%), and 20/20 (100\%) leaves produced sporangia. In addition, in the first two trials, which were surveyed daily, the majority of bay leaves ( 85 and $55 \%$ ) produced sporangia within $48 \mathrm{~h}$. Chlamydospores also were present on the surface of most leaves in the three trials $(80,80$, and $100 \%)$. From the field observation of bay laurel leaves under natural conditions during storms, 19/20 (95\%) and 15/20 (75\%) produced sporangia. For the second field trial, the mean number of zoospores produced from sporangia on leaves was 1,173.0 \pm SE 301.48 and the range was 0 to 5,265 spores. Although zoospores were not quantified for the first field trial, observations indicated that numbers of sporangia were much greater than in the second trial.

Temperature significantly affected the production of sporangia from bay laurel leaves in both laboratory trials (trial $1: F=8.18$, df $=4, P<0.0001, n=75$; trial $2: F=3.36$, df $=4, P=0.01, n=$ 75) (Fig. 1A and B). Zoospores were produced at all temperatures except for $30^{\circ} \mathrm{C}$, and ranged up to 2,460 spores per leaf disk at $15^{\circ} \mathrm{C}$. In the first trial, the number of zoospores produced at $15^{\circ} \mathrm{C}$ was significantly higher than the numbers produced at 5,10 , and $25^{\circ} \mathrm{C}$ (Tukey's honestly significant difference [HSD], $P<0.05$ ). The number of zoospores produced at $20^{\circ} \mathrm{C}$ was significantly higher than the number produced at $5^{\circ} \mathrm{C}(P<0.05)$, and tended to be higher than the numbers produced at 10 and $25^{\circ} \mathrm{C}$. In the second trial, there were fewer significant differences in zoospore production between the different temperatures; only the $25^{\circ} \mathrm{C}$ treatment was significantly higher than the $5^{\circ} \mathrm{C}$ treatment $(P<$ $0.05)$. However, the numbers of zoospores produced at 15 and $20^{\circ} \mathrm{C}$ tended to be higher than the numbers produced at 5 and $10^{\circ} \mathrm{C}$.

Transmission pathways and seasonality of inoculum. Rainwater. $P$. ramorum was recovered from rainwater. The concentration of $\mathrm{CFU}$ in rainwater as quantified on PARP plates varied greatly among individual trap sites in the forest, throughout the rainy season, and among the 3 years (Fig. 2B). Mean CFU/liter for individual traps ranged between 0.11 and 34.61, with an overall mean of $11.69 \pm$ SE 1.93 . CFU/liter varied significantly among the 3 years (least squares means 2000-01: $0.33 \pm$ SE 0.77 versus 2001-02: $0.49 \pm$ SE 0.99 versus 2002-03: $31.77 \pm$ SE 6.86; $F=$ 10.38 , df $=2, P=0.0003, n=37)$. The 2002-03 season showed significantly higher spore production than the other two years (Tukey's HSD, $P<0.05$ ). For the 2 years in which spore production was quantified throughout the entire rainy season, spore production was absent or low for the first part of the rainy season and highest at the end of the rainy season $(2001-02: F=7.73, P=$ $0.02, r^{2}=0.37, n=15 ; 2002-03: F=8.34, P=0.01, r^{2}=0.43$, $n=13)$. The relationship between spore production and time (days) into the rainy season was nonsignificant for 2000-01, the first year of the study. However, data collection did not begin until midway through the rainy season in February 2001. Possible explanatory variables for the observed seasonal pattern in 200102 and 2002-03, such as mean daily high temperature, mean daily low temperature, and mean daily rainfall during a rain event, were not consistently correlated with spore production in both of the two complete rainy seasons (Fig. 2A and B). In 2001-02, mean high daily temperature was significantly correlated with CFU/liter $\left(F=4.72, P=0.05, r^{2}=0.28, n=12\right)$. In 2002-03, there were no significant models with these variables $(P>0.2)$. $P$. ramorum was not recovered from isolated rain events during the summer months.

Spore movement in rainwater from the forest edge to rain trap buckets placed in the meadow declined with distance from the forest edge (Fig. 3) $\left(F=6.25, P=0.01, r^{2}=0.07, n=84\right)$. Overall, of the 60 samples on five rain dates from the buckets at $0 \mathrm{~m}$, $24(40 \%)$ were positive. Although most of the 5- and 10-m samples were negative, propagules did reach these buckets for $9 / 60$ 
(15\%) 5-m samples and 6/60 (10\%) 10-m samples. When $P$. ramorum was recovered at these distances, the inoculum load could be quite high. The highest counts of 530 and $437 \mathrm{CFU} /$ liter for 5 and $10 \mathrm{~m}$, respectively, both occurred with the rain event of 16 to 22 April 2003 (as did the highest count for $0 \mathrm{~m}$ ). In addition, one of the two $15-\mathrm{m}$ samples was positive for $P$. ramorum from the 12 to 13 April rain event. A single colony of $P$. ramorum grew from this $15-\mathrm{m}$ sample.

Soil and litter. Soil and litter contained viable propagules of $P$. ramorum (Fig. 2C and D). Percent positive samples ranged from 0 to 93 and 0 to $100 \%$ for soil and litter, respectively. The percentage of positive samples of soil and litter were significantly correlated with the mean CFU/liter for all rain events by month
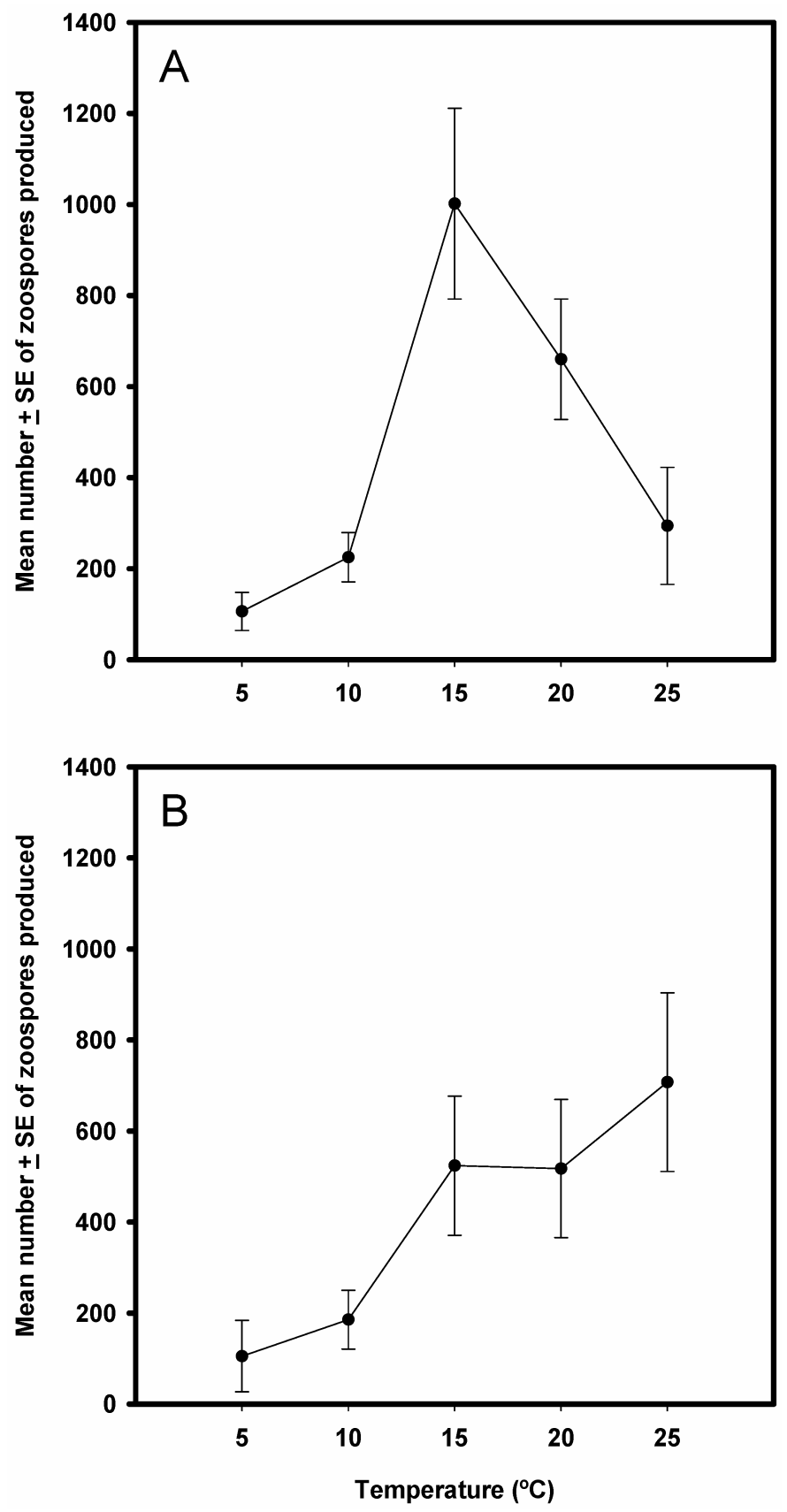

Fig. 1. Mean number \pm SE of zoospores produced on infected bay laurel leaf disks incubated at various temperatures in experimental trial 1 (A) and trial 2 (B). The $25^{\circ} \mathrm{C}$ temperature may be a threshold temperature for direct germination of sporangia versus zoospore production (D. Rizzo, unpublished data), potentially leading to large differences in the number of zoospores produced per leaf at this temperature. Daily high temperatures during rain events at the Fairfield Osborn Preserve study site rarely reach $25^{\circ} \mathrm{C}$. (soil: $F=15.15, P=0.001, r^{2}=0.46, n=20$; litter: $F=22.23$, $\left.P=0.0002, r^{2}=0.57, n=19\right)$. The greatest percentage of positive samples occurred in 2003, the year with the most precipitation late in the rainy season and the highest concentration of spores in rainwater. Propagules were not detectable during the summer dry season in either soil or litter beginning in June 2001 and 2002 and July 2003. In 2003, when soil water content was monitored, the failure to detect $P$. ramorum in soil during the summer coincided with a drop in mean soil water content to $<15 \%$.

$P$. ramorum was recovered from the soil of hikers' shoes after they walked $2.4 \mathrm{~km}$ on a preserve trail. Soil from shoes yielded $7 / 15(46.7 \%)$ and $5 / 15(33.3 \%)$ positive samples during the two trials in April 2003.

Inoculum spread from infested soil to infect green leaf litter and, in a second experiment, from infested green leaf litter to the aboveground leaves on seedlings. In the first experiment, testing the transmission of $P$. ramorum from zoospores in soil to green bay laurel leaves on the soil surface, $6 / 15(40 \%)$ and $1 / 15(6.7 \%)$ of bay laurel leaves were infected in the two trials by the end of the 6 -week period. In the second experiment, 3 and 10 bay laurel leaves on seedlings were infected from infested leaf litter during the first and second trials, respectively. No control seedling leaves were infected.

Streamwater. $P$. ramorum was recovered from the ephemeral stream at FOP using pear baiting during one of two sampling periods in 2001-02 and five of seven sampling dates during the 2003 rainy season. In 2003, the percentage of positive pear fruit was greatest toward the end of the rainy season during March, April, and May. In the 2003 downstream sampling, P. ramorum was recovered at the forested site and the riparian site in pasture 4 and $6 \mathrm{~km}$ from the preserve, respectively. In the first trial, FOP and the two sites were positive for $P$. ramorum. In the second trial, only the forested site was positive for P. ramorum. Drying of the ephemeral stream at FOP may have prevented infection of leaves at this site in the second trial.

\section{DISCUSSION}

Although $P$. ramorum appears remarkable in its ability to infect many hosts, spread into new geographic areas, and escape from nursery settings, its pathways of transmission are predictably consistent with those of other aerial Phytophthora spp. Propagules of $P$. ramorum found in rainwater collected from this infested coast live oak-bay laurel forest ranged up to $510 \mathrm{CFU} /$ liter. Given that propagules of $P$. ramorum were present in rainwater, it is not unexpected that they also would occur on or in substrates where rain falls, such as soil, litter, and streamwater. Other aerial Phytophthora spp. such as $P$. cactorum, $P$. capsici, . palmivora, and $P$. parasitica disperse via rain splash from infections on aboveground plant parts $(3,4,18,23,27,35,44,49)$. Many Phytophthora spp. have been found to be present in or to disperse from soil, including $P$. botryosa, $P$. cactorum, $P$. cinnamomi, $P$. lateralis, $P$. megakarya, $P$. palmivora, and $P$. syringae $(12,17,20,34,50,59)$. Likewise, a number of species such as $P$. capsici, $P$. cinnamomi, $P$. gonapodyides, and $P$. lateralis disperse via watercourses $(7,19$, 20,31,59).

The source of $P$. ramorum inoculum in rainwater in mixedevergreen forests is most likely sporangia and zoospores produced from infections on bay laurel leaves. Of the infected bay laurel leaves tested in the laboratory, 85 to $100 \%$ produced sporangia. Our measurement of zoospores produced on bay laurel leaves under natural field conditions averaged 1,173.0 \pm SE 301.48 spores per leaf. This is a large quantity considering that tens to hundreds of leaves generally are infected on each tree, combined with the high incidence of infection $(81.9 \%)$ on bay laurel trees in our main woodland study site.

In this study, sporangia were observed almost entirely on the underside of infected bay laurel leaves. Production of sporangia 
on the underside of leaves does not appear to be due to moisture requirements, because the underside of leaves often were observed to dry faster than the topside of leaves where water pooled at the drip tip. Instead, sporangia may be formed on the underside of the leaf due to anatomical constraints such as the position of the stomates on the lower side of the leaf or thicker cuticle on the top versus the bottom of the leaf. Protection from deleterious UV light also may lead to evolution of abaxial sporangia production.
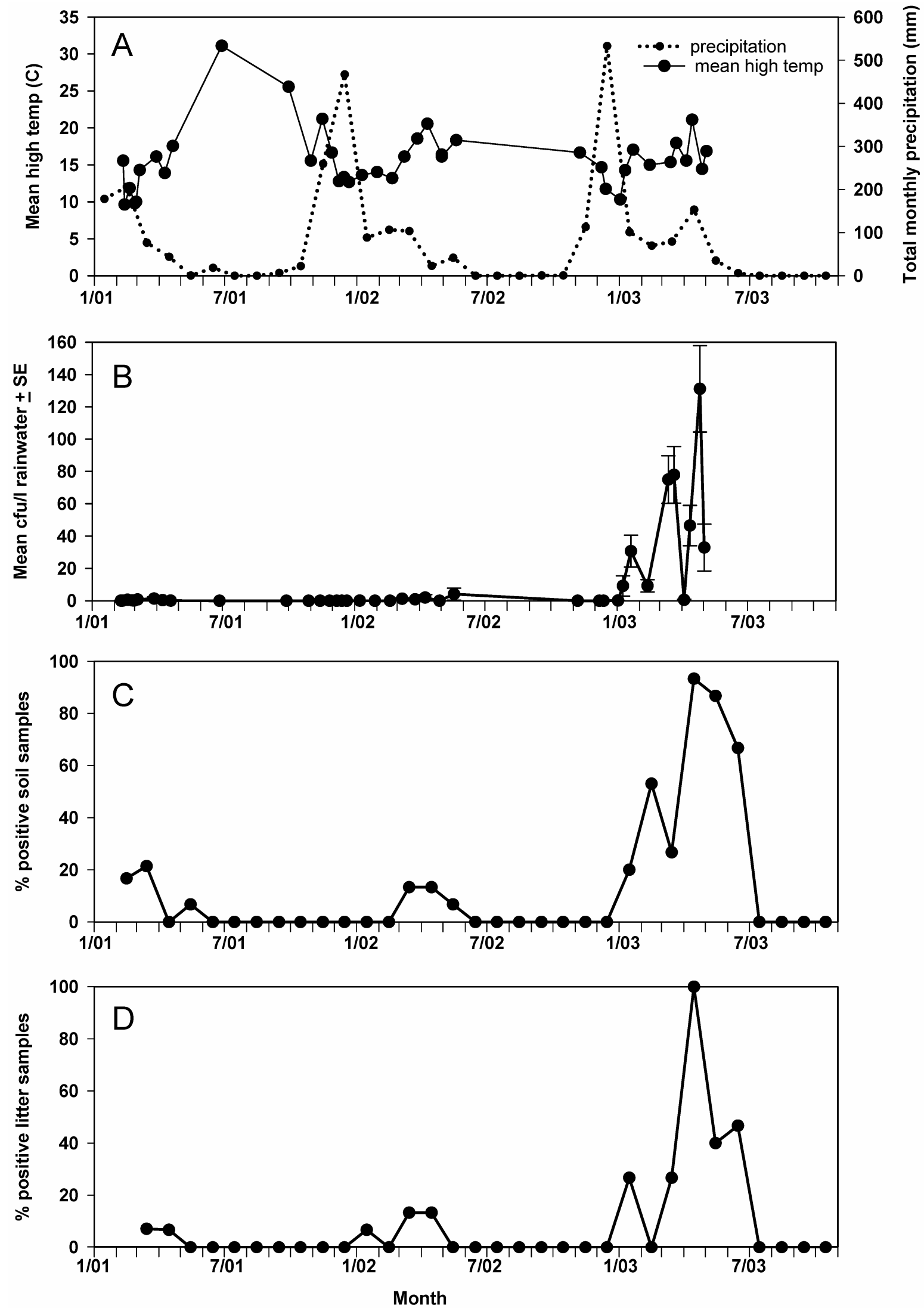

Fig. 2. A, Weather conditions, $\mathbf{B}$, concentration of inoculum (CFU) in rainwater, $\mathbf{C}$, percent positive soil samples, and $\mathbf{D}$, percent positive litter samples for the period of January 2001 through October 2003. Mean high temperatures in A correspond to each monitored rain event in $\mathbf{B}$. 
Our experimental evidence demonstrates the importance of bay laurel leaves for inoculum production by $P$. ramorum. This coincides with previous forest surveys that correlated the presence of bay laurel trees with $P$. ramorum infection on oak and tanoak trees in California forests across the landscape $(30,52)$. In addition, P. E. Maloney (unpublished data) found higher levels of inoculum in rainwater collected from under bay laurel trees compared with under other tree species in tanoak-redwood forest in California.

The significance of bay laurel leaves for transmission of $P$. ramorum has been established only for forests in California. $P$. ramorum may not be spreading as quickly in Oregon as it is in California, although bay laurel is present at infested forest sites (E. Hansen, unpublished data). Interactions between bay laurel and $P$. ramorum populations at other sites need to be researched to predict transmission pathways for $P$. ramorum throughout different forest types in its present and potential geographic range.

In contrast to the foliar infections on bay laurel, trunk infections on coast live oak do not appear to be a source of inoculum. Although $P$. ramorum can cause mortality of oak trees, it does not appear to reproduce from infected bark. Therefore, in forests, coast live oak can be considered an epidemiological "dead end" host for $P$. ramorum.

Theory based on single-host pathogens suggests that evolution of virulence on a host usually is inversely related to the degree to which the pathogen can reproduce from the host (60). Although $P$. ramorum is a multihost pathogen, the nonlethal foliar infections of bay laurel and the lethal infections on oak trunks appear consistent with theory. Based on the high capacity for reproduction from bay laurel leaves, $P$. ramorum should evolve nonlethal infections on this host. However, given that $P$. ramorum cannot reproduce from oak trees, there is no selection pressure for decreased virulence. Alternatively, given that $P$. ramorum is likely to have been introduced within the past 20 years $(46,47)$ and has not had much evolutionary time with plant hosts in California woodlands, it may be that levels of virulence do not reflect evolutionary trajectories within the California geographic range, but are reflective of evolution on similar hosts in the pathogen's native range.

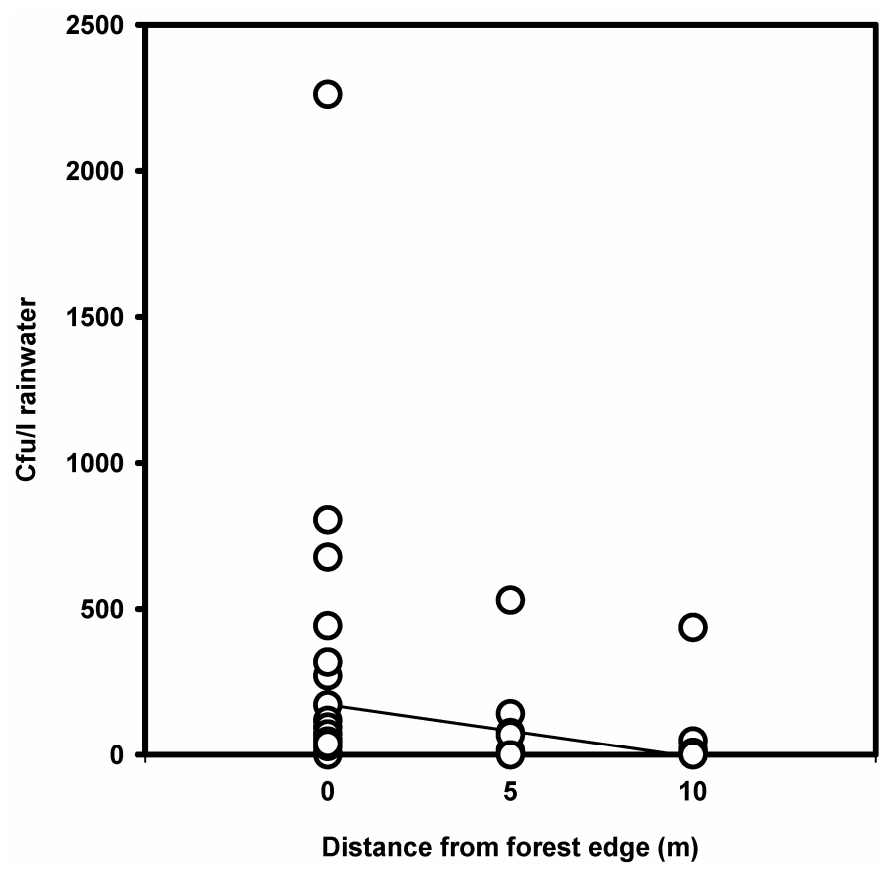

Fig. 3. Concentration of inoculum in rainwater collected in buckets placed in a meadow at 0,5 , and $10 \mathrm{~m}$ from infected bay laurel trees at the forest edge. Although concentration of spores declined with distance from the forest edge, $9 / 60(15 \%)$ of the $5-\mathrm{m}$ samples and $6 / 60(10 \%)$ of the $10-\mathrm{m}$ samples were positive for Phytophthora ramorum.
Although spores were not noted on the intact bark surface of the oak cankers in the moist chamber experiment, hyphae of $P$. ramorum did grow from the cut surface of phloem into the water and formed chlamydospores for 2 of the 15 trees. This does not represent transmission under natural situations where oak trees are standing and the bark is intact, but may pose a risk for timber or firewood that is cut to expose infected phloem and then stored in moist areas where water puddles.

Detectable levels of $P$. ramorum inoculum were present in mixed-evergreen forest largely during the period of winter rains, and were absent during the hot, dry summer. This is consistent with the fact that Phytophthora spp. generally require very high moisture levels nearing $100 \%$ humidity for sporangia production (12). Interestingly, we observed a lag period between the start of the rains and the onset of detectable inoculum production for three consecutive years that may be characteristic of sporangia production from bay laurel leaves in mixed-evergreen forest (Fig. $2 \mathrm{~A}$ and $\mathrm{B})$. This lag may be due to a considerable decrease in the inoculum reservoir during the hot, dry summer months through (i) abscission of infected leaves from the canopy and (ii) death or deep dormancy of $P$. ramorum in the majority of remaining attached, infected leaves (J. Davidson, unpublished data). The onset of detectable inoculum production in mixed-evergreen forest may depend on breaking dormancy for isolates that over-summered in bay laurel leaves, and a subsequent build-up of infection on bay laurel leaves.

Temperature also may influence the quantity of sporangia produced on leaf tissue in the early rainy season once dormancy is broken. $P$. ramorum produced sporangia in laboratory studies at temperatures that were similar to average rain event temperatures at the field site during the coldest early winter rains. However, the laboratory trials suggest that lower temperatures during these early rains may lead to lower sporangia production, and thereby contribute to the observed lag period. At lower temperatures, insufficient numbers of sporangia may be present to meet threshold levels for infection. In addition, for a given inoculum concentration, infection rates on bay leaves are decreased at lower temperatures (26). Slower accumulation of new infections on bay leaves during early winter rains would limit the build-up of inoculum in the forest.

Although temperature may influence the quantity of sporangia produced, the relationship between temperature and sporulation in the field is not always consistent and may be confounded by other factors. Concentration of CFU in rainwater increased significantly toward the end of the rainy season in the spring of each of the two complete years that were monitored. In 2001-02, this increase in CFU/liter was positively correlated with temperature: mean high temperatures during rain events dropped in December, January, and February, and then increased in March, April, and May when CFU/liter increased. However, in 2002-03, temperature was not predictive of $\mathrm{CFU} /$ liter. In this year, mean high temperatures dropped only in December, and then were generally higher, but did not significantly increase throughout the rest of the season even though CFU/liter continued to rise (Fig. 2A and B). Other factors associated with the late rainy season apart from temperature may drive the pattern of higher spore production. For example, incidence of infection on bay laurel leaves in mixed-evergreen forest increases throughout the rainy season (J. Davidson, unpublished data), and higher numbers of infected bay laurel leaves at the end of the rainy season may lead to higher concentrations of inoculum in rainwater.

Regardless of the mechanism underlying increased spore production in mixed-evergreen forests at the end of the rainy season, extended rains, particularly in wet or El Niño years, may be pulse years for heightened inoculum pressure and significantly increased infection incidence on coast live oak trees and other hosts (46). For example, the peak of April rains in 2003 (Fig. 2A) may have contributed toward the two-order-of-magnitude increase in 
spore production over the previous 2 years, and a corresponding $10.4 \%$ increase in infection incidence on coast live oak at the study site. Swiecki and Bernhardt (53) also reported an increase in oak infections in their field plots following the 2003 rains, in contrast to no new infections in the previous 2 years. The epidemic mortality on coast live oak trees 1 to 2 years after the 1998 El Niño also may be representative of this process.

Extended rains in April 2003 cannot solely explain the two-order-of-magnitude increase in inoculum in rainwater during the 2002-03 rainy season. Markedly higher levels of spore production were evident beginning in January 2003 (Fig. 2A and B). Only through long-term monitoring and experimentation will we have the opportunity to understand remarkable seasons like 2002-03 and to identify additional mechanisms underlying upswings in epidemiological cycles of $P$. ramorum.

Inoculum of $P$. ramorum was not detected in soil or litter shortly after the rains stopped or throughout the summer months using pear baiting methods. This indicates that soil and litter were no longer infective using our method of wetting the soil for 6 days. However, the viability of $P$. ramorum propagules, especially dormant chlamydospores, in soil is still in question. Additional baiting methods designed to break dormancy of resting spores should be employed to further test viability of $P$. ramorum inoculum in soil during summer periods of increased temperatures and markedly lower soil moisture. It is necessary to understand whether soil can serve as a reservoir of inoculum during the summer months and a source of primary inoculum once the winter rains arrive.

This study provides the first estimates of the distances that $P$. ramorum can travel through rain splash, streamwater, and soil. Although dispersal distance in rainwater was tested on only five rain dates, rain splash carried spores of $P$. ramorum over distances of 5 and $10 \mathrm{~m}$ on four and three of the sampled rain dates, respectively. On one date, a propagule traveled to the $15-\mathrm{m}$ rain bucket. Consequently, movement of spores in windblown rain over distances of 5 and $10 \mathrm{~m}$ probably is not unusual in unobstructed space, such as above the canopy or into gaps. Unusually high winds associated with rarer storm events may blow raindrops with spores over distances greater than $15 \mathrm{~m}$ and potentially serve as unique long-distance dispersal events that increase transmission rates and create new infection centers. Other estimates of movement of sporangia of Phytophthora spp. in windblown rain include $P$. capsici and $P$. palmivora moving 3 and $12 \mathrm{~m}$, respectively $(35,44)$.

$P$. ramorum has great potential to move over long distances through dispersal via streamwater. This study detected the presence of $P$. ramorum by rhododendron leaf baiting at a riparian site in open pasture $1 \mathrm{~km}$ downstream from coast live oak-bay laurel forest. This is not surprising given that $P$. ramorum zoospores can survive up to 6 months in $\mathrm{diH}_{2} \mathrm{O}$ in the laboratory (J. Davidson, unpublished data). Long-term survival of spores in water will allow for long-distance movement in running streamwater depending on water speed, buoyancy of spores, chemical composition of water, and predation of spores. P. lateralis, a root pathogen, has spread many kilometers along stream courses via infecting roots of Port-Orford cedar (Chamaecyparis lawsoniana) that border the stream $(20,29)$. P. ramorum is an aerial pathogen; therefore, movement to aerial parts of plants will be necessary for infection. This could occur through infection of overhanging branches (7), movement via wading animals, or movement via human removal of water for agriculture or dust abatement $(32,37,39,54)$.

Infested soil has the potential to spread $P$. ramorum over both long and short distances. This study demonstrated a transmission pathway by which $P$. ramorum could spread from infested soil to bay laurel green leaf litter and then infect leaves of bay laurel seedlings via splash dispersal. Under natural conditions, this could involve infection of bay laurel green leaf litter blown down in winter storms and the subsequent infection of forest bay laurel seedlings. Other studies also have demonstrated the movement of direct splash dispersal of Phytophthora spp. from soil to infect stems, leaves, and fruits of plants $(12,17,34)$. Our finding of the infested soil on the shoes of hikers at FOP demonstrates a substantial risk for long-distance movement of inoculum (see also 55) and then infection of plants from soil by the processes described above. Long-distance dispersal events often are key events in the rapid spread of pathogens to new geographic locations (8).

This article describes mechanisms of transmission for P. ramor$u m$ involving spore production and movement in mixed-evergreen forests dominated by coast live oak and bay laurel. Spores of $P$. ramorum are produced from nonlethal foliar infections on bay laurel and then, like other aerial Phytophthora spp., spread over significant distances within woodlands via rain splash, stream flow, and movement of infested soil. These transmission pathways make $P$. ramorum difficult to contain once it establishes in a mixed-evergreen forest. Future research should investigate the next step in the disease cycle and determine requirements for infection of both bay laurel and coast live oak. Investigations also are needed to characterize the over-summering reservoir inoculum in bay laurel leaves that will serve as the primary inoculum source during the subsequent rainy season. These studies should be extended to multiple populations of dominant host species in other forest types to effectively forecast infection periods for $P$. ramorum in the numerous forest types and climates throughout its geographic range.

\section{ACKNOWLEDGMENTS}

This research was made possible by funding from the U.S. Department of Agriculture Forest Service Pacific Southwest Research Station and the Gordon and Betty Moore Foundation. We thank A. Adie, R. Albright, J. Bienapfl, A. Cass, J. Clothier, K. Covington, K. Crandall, L. Douhan, C. Friel, P. Galbreath, A. Gibson, R. Gross, K. Hayden, K. Huryn, C. Jensen, S. Langley, S. Lynch, P. Patterson, D. Prieto, G. Slaughter, S. Swain, M. Voigt, G. Walden, and J. Zanzot for their superb assistance; J. Clothier for providing weather data for Fairfield Osborn Preserve; the Marin Open Space District, Camp Tamarancho, China Camp State Park, and especially Sonoma State University and Fairfield Osborn Preserve for permitting research in their forests; and L. Kinkel and two anonymous reviewers for their constructive comments.

\section{LITERATURE CITED}

1. APHIS. Pest Detection and Management Programs: Program Update Sudden Oak Death March 26, 2004. Published online by APHIS.

2. Barbour, M. G., and Billings, W. D. (eds.) 2000. North American Terrestrial Vegetation. Cambridge University Press, Cambridge.

3. Benson, D. M., and Campbell, C. L. 1985. Spatial pattern of Phytophthora root rot and dieback of azalea in container-grown nursery stock. Plant Dis. 69:1049-1054.

4. Bowers, J. H., and Mitchell, D. J. 1991. Relationship between inoculum level of Phytophthora capsici and mortality of pepper. Phytopathology 81:178-184.

5. Brasier, C., and Kirk, S. 2004. Production of gametangia by Phytophthora ramorum in vitro. Mycol. Res. 108:823-827.

6. Burns, R. M., and Honkala, B. H. (eds.) 1990. Silvics of North America: Volume 2, Hardwoods. U.S. Dep. Agric. For. Serv., Washington, DC.

7. Café-Filho, A. C., and Duniway, J. M. 1995. Dispersal of Phytophthora capsici and P. parasitica in furrow-irrigated rows of bell pepper, tomato and squash. Plant Pathol. 44:1025-1032.

8. Campbell, C. L. 1999. The importance of dispersal mechanisms in the epidemiology of Phytophthora blights and downy mildews on crop plants. Ecosyst. Health 5:146-157.

9. Davidson, J. M., Garbelotto, M., Koike, S. T., and Rizzo, D. M. 2002. First report of Phytophthora ramorum on Douglas-fir in California. Plant Dis. 86:1274.

10. Davidson, J. M., Rizzo, D. M., Garbelotto, M., Tjosvold, S., and Slaughter, G. W. 2002. Phytophthora ramorum and sudden oak death in California: II. Transmission and survival. Pages 741-749 in: Proc. Fifth Symp. Oak Woodlands: Oak Woodlands in California's Changing Landscape, San Diego, CA. Gen. Tech. Rep. PSW-GTR-184. R. B. Standiford, D. McCreary, and K. L. Purcell, eds. Pacific Southwest Research Station, Forest Service, United States Department of Agriculture, Albany, CA. 
11. Davidson, J. M., Werres, S., Garbelotto, M., Hansen, E. M., and Rizzo, D. M. 2003. Sudden oak death and associated diseases caused by Phytophthora ramorum. Online. Plant Health Progress doi:10.1094/PHP-20030707-01-DG.

12. Erwin, D. C., and Ribeiro, O. K. 1996. Phytophthora Diseases Worldwide. The American Phytopathological Society, St. Paul, MN.

13. Garbelotto, M., Davidson, J. M., Ivors, K., Maloney, P. E., Huberli, D., Koike, S. T., and Rizzo, D. M. 2003. Non-oak native plants are main hosts for sudden oak death pathogen in California. Calif. Agric. 57:18-23.

14. Garbelotto, M., Rizzo, D. M., and Marais, L. 2002. Phytophthora ramorum and sudden oak death in California: IV. Chemical control. Pages 811-818 in: Proc. Fifth Symp. Oak Woodlands: Oak Woodlands in California's Changing Landscape, San Diego, CA. Gen. Tech. Rep. PSWGTR-184. R. B. Standiford, D. McCreary, and K. L. Purcell, eds. Pacific Southwest Research Station, Forest Service, United States Department of Agriculture, Albany, CA.

15. Goheen, E. M., Hansen, E. M., Kanaskie, A., McWilliams, M. G., Osterbauer, N., and Sutton, W. 2002. Eradication of sudden oak death in Oregon. (Abstr.) Phytopathology 92(suppl.):S30.

16. Goheen, E. M., Hansen, E. M., Kanaskie, A., McWilliams, M. G., Osterbauer, N., and Sutton, W. 2002. Sudden oak death caused by Phytophthora ramorum in Oregon. Plant Dis. 86:441.

17. Gregory, P. H., Griffin, M. J., and Maddison, M. R. 1984. Cocoa black pod: A reinterpretation. Cocoa Grow. Bull. 35:5-22.

18. Grove, G. G., Madden, L. V., and Ellis, M. A. 1985. Splash dispersal of Phytophthora cactorum from infected strawberry fruit. Phytopathology 75:611-615.

19. Hansen, E., and Delatour, C. 1999. Phytophthora species in oak forests of north-east France. Ann. For. Sci. 56:539-547.

20. Hansen, E. M., Goheen, D. J., Jules, E. S., and Ullian, B. 2000. Managing Port-Orford-cedar and the introduced pathogen Phytophthora lateralis. Plant Dis. 84:4-14.

21. Hansen, E. M., Reeser, P. W., Sutton, W., and Winton, L. M. 2003. First report of A1 mating type of Phytophthora ramorum in North America. Plant Dis. 87:1267

22. Hardy, G. E., Barrett, S., and Shearer, B. L. 2001. The future of phosphite as a fungicide to control the soil-borne plant pathogen Phytophthora cinnamomi in natural ecosystems. Australas. Plant Pathol. 30:133-139.

23. Hartman, G. L., Huang, Y. H., and Wang, T. C. 1991. Infection of pepper and tomato by Phytophthora capsici. Plant Dis. 75:751.

24. Hickman, J. C. (ed.) 1993. The Jepson Manual: Higher Plants of California. The University of California Press, Berkeley and Los Angeles.

25. Hüberli, D., Reuther, K. D., Smith, A., Swain, S., Tse, J. G., and Garbelotto, M. 2004. First report of foliar infection of Rosa gymnocarpa by Phytophthora ramorum. Plant Dis. 88:430.

26. Hüberli, D., Van Sant, W., Swain, S., Davidson, J. M., and Garbelotto, M. 2003. Susceptibility of Umbellularia californica to Phytophthora ramorum. Presented at Eighth Int. Congr. Plant Pathol. Christchurch, New Zealand.

27. Hunter, J. E., and Kunimoto, R. K. 1974. Dispersal of Phytophthora palmivora sporangia by wind-blown rain. Phytopathology 64:202-206.

28. Ivors, K. L., Hayden, K. J., Bonants, P. J. M., Rizzo, D. M., and Garbelotto, M. 2004. AFLP and phylogenetic analyses of North America and European populations of Phytophthora ramorum. Mycol. Res. 108:378-392.

29. Jules, E. S., Kauffman, M. J., Ritts, W. D., and Carroll, A. L. 2002. Spread of an invasive pathogen over a variable landscape: A nonnative root rot on Port Orford cedar. Ecology 83:3167-3181.

30. Kelly, N. M., and Meentemeyer, R. 2002. Landscape dynamics of the spread of sudden oak death. Photogrammetric Eng. Remote Sens. 68:1001-1009.

31. Kinal, J., Shearer, B. L., and Fairman, R. G. 1993. Dispersal of Phytophthora cinnamomi through lateritic soil by laterally flowing subsurface water. Plant Dis. 77:1085-1090.

32. Klotz, L. J., Wong, P. P., and DeWolfe, T. A. 1959. Survey of irrigation water for the presence of Phytophthora spp. pathogenic to citrus. Plant Dis. Rep. 43:830-832.

33. Levene, H. 1960. Robust tests for equality of variance. Pages 278-292 in: Contributions to Probability and Statistics. I. Olkin, ed. Stanford University Press, Palo Alto, CA

34. Madden, L. V., Wilson, L. L., Yang, X., and Ellis, M. A. 1992. Splash dispersal of Colletotrichum acutatum and Phytophthora cactorum by short-duration simulated rains. Plant Pathol. 41:427-436.

35. Maddison, A. C., and Grifffin, R. L. 1971. Detection and movement of inoculum. Pages 31-49 in: Epidemiology of Phytophthora on Cocoa in Nigeria. P. H. Gregory and A. C. Maddison, eds. Phytopathol. Pap. No. 25. Commonwealth Mycological Institute, Kew, Surrey, London.
36. Maloney, P. E., Rizzo, D. M., Koike, S. T., Harnik, T. Y., and Garbelotto, M. 2002. First report of Phytophthora ramorum on coast redwood in California. Plant Dis. 86:1274.

37. McIntosh, D. L. 1966. The occurrence of Phytophthora spp. in irrigation systems in British Columbia. Can. J. Bot. 44:1591-1596.

38. Miller, V. C. 1972. Sonoma County Soil Survey. Soil Conservation Science, United States Department of Agriculture, Washington, DC.

39. Mircetich, S. M., Browne, G. T., Krueger, W., and Schreader, W. 1985 Phytophthora spp. isolated from surface-water irrigation sources in California. (Abstr.) Phytopathology 75:1346.

40. Mitchell, C. E. 2003. Trophic control of grassland production and biomass by pathogens. Ecol. Lett. 6:147-155.

41. Neter, J., Wasserman, W., and Kutner, M. H. 1990. Applied Linear Statistical Models. Richard D. Irwin, Inc., Boston.

42. Osterbauer, N., Griesbach, J. A., and Hedberg, J. 2004. Surveying for and eradicating Phytophthora ramorum in agricultural commodities. Online. Plant Health Progress doi:10.1094/PHP-2004-0309-02-RS.

43. Pavlik, B. M., Muick, P. C., Johnson, S. G., and Popper, M. 1991. Oaks of California. Cachuma Press, Los Olivos, CA.

44. Ramachandran, N., Sarma, Y. R., and Anandaraj, M. 1990. Vertical progression and spread of Phytophthora leaf infection in black pepper in areca-black pepper mixed cropping system. Indian Phytopathol. 43:414419.

45. Ristaino, J. B., and Gumpertz, M. L. 2000. New frontiers in the study of dispersal and spatial analysis of epidemics caused by species in the genus Phytophthora. Annu. Rev. Phytopathol. 38:541-576.

46. Rizzo, D. M., and Garbelotto, M. 2003. Sudden oak death: Endangering California and Oregon forest ecosystems. Frontiers Ecol. Environ. 1:197204.

47. Rizzo, D. M., Garbelotto, M., Davidson, J. M., Slaughter, G. W., and Koike, S. T. 2002. Phytophthora ramorum as the cause of extensive mortality of Quercus spp. and Lithocarpus densiflorus in California. Plant Dis. 86:205-214

48. SAS. 2004. JMP IN 5.1. SAS Institute, Inc., Cary, NC.

49. Schlub, R. L. 1983. Epidemiology of Phytophthora capsici on bell pepper. Camb. J. Agric. Sci. 100:7-11.

50. Shea, S. R., Shearer, B. L., Tippett, J. T., and Deegan, P. M. 1984. Distribution, reproduction, and movement of Phytophthora cinnamomi on sites highly conducive to jarrah dieback in south Western Australia. Plant Dis. 67:970-973.

51. Sokal, R. R., and Rohlf, F. J. 1994. Biometry. W. H. Freeman \& Co., New York.

52. Swiecki, T. J., and Bernhardt, E. 2002. Evaluation of stem water potential and other tree and stand variables as risk factors for Phytophthora ramorum canker development in coast live oak. Pages 787-798 in: Proc. Fifth Symp. Oak Woodlands: Oak Woodlands in California's Changing Landscape, San Diego, CA. Gen. Tech. Rep. PSW-GTR-184. R. B. Standiford, D. McCreary, and K. L. Purcell, eds. Pacific Southwest Research Station, Forest Service, United States Department of Agriculture, Albany, CA.

53. Swiecki, T. J., and Bernhardt, E. 2004. Phytophthora ramorum canker: Factors affecting disease progression and failure potential (20032004 annual report). Published online by Phytosphere Research, Vacaville, CA.

54. Thompson, S. V., and Allen, R. M. 1974. Occurrence of Phytophthora species and other potential plant pathogens in recycled irrigation water. Plant Dis. Rep. 58:945-949.

55. Tjosvold, S. A., Chambers, D. L., Davidson, J. M., and Rizzo, D. M. 2002. Incidence of Phytophthora ramorum inoculum found in soil collected from a hiking trail and hikers' shoes in a California park. Presented at Sudden Oak Death Science Symposium: The State of Our Knowledge, Monterey, CA.

56. Welch, B. L. 1951. On the comparison of several mean values: An alternative approach. Biometrika 38:330-336.

57. Werres, S., Marwitz, R., Man in't Veld, W. A., De Cock, A. W. A. M., Bonants, P. J. M., De Weerdt, M., Themann, K., Ilieva, E., and Baayen, R. P. 2001. Phytophthora ramorum sp. nov., a new pathogen on Rhododendron and Viburnum. Mycol. Res. 105:1155-1165.

58. Werres, S., and Zielke, B. 2003. First studies on the pairing of Phytophthora ramorum. J. Plant Dis. Prot. 110:129-130.

59. Weste, G. 1983. Population dynamics and survival of Phytophthora. Pages 237-258 in: Phytophthora: Its Biology, Taxonomy, Ecology, and Pathology. D. C. Erwin, S. Bartnicki-Garcia, and P. H. Tsao, eds. The American Phytopathological Society, St. Paul, MN.

60. Woolhouse, M. E., Taylor, L. H., and Haydon, D. T. 2001. Population biology of multihost pathogens. Science 292:1109-1112. 